\title{
Exploring Students-Teacher Interaction in Dialogic Reading of Descriptive Texts
}

\author{
Annisa Sita Herdanti ${ }^{1}$ Hilmansyah Saefullah ${ }^{2}$ \\ English Education Department, Universitas Singaperbangsa Karawang, Karawang \\ * Corresponding Author. E-mail: annisasita36@gmail.com
}

Receive: 13/05/2021

Accepted: 23/08/2021

Published: 01/10/2021

\begin{abstract}
Abstrak
Interaksi antara siswa dan guru di dalam kelas merupakan bagian penting dari pembelajaran bahasa. Membaca dialogis merupakan salah satu strategi pembelajaran yang tepat untuk memfasilitasi interaksi siswa dan guru EFL di dalam kelas. Membaca dialogis menekankan pada interaksi antara orang dewasa dan anak-anak dalam hal ini siswa dan guru, guru menggunakan berbagai teknik pertanyaan seperti strategi 'CROWD' dalam membaca dialogis. Oleh karena itu, penelitian ini bertujuan untuk mengeksplorasi interaksi siswa dan guru pada dialogic reading dalam pembelajaran membaca teks bahasa Inggris. Peneliti memilih metode mikroetnografi untuk mendapatkan gambaran yang jelas tentang interaksi antara guru dan siswa dalam setting EFL. Strategi ini diterapkan di SMP Negeri di Purwakarta, dengan peserta guru bahasa Inggris dan sepuluh siswa SMP. Hasil penelitian ini menunjukkan bahwa guru berinteraksi dengan siswa menggunakan strategi 'CROWD' seperti 1) prompt mengingat, 2) prompt terbuka, 3) prompt Wh, dan 4) perintah jarak. Dan juga terdapat kategori interaksi FIAC dalam strategi CROWD.
\end{abstract}

Kata Kunci: Interaksi kelas, dialogic reading, pengaturan EFL

\begin{abstract}
The interaction between students and teachers in the classroom is an important part of language learning. Dialogic reading can be an appropriate learning strategy to facilitate EFL students' and teacher's interaction in the classroom. This research aims to explore the students and teacher interaction on dialogic reading in learning reading English text. Micro-ethnography classroom research was employed to get a clear description of the interaction between the teacher and students in an EFL setting. The participants in this study were an English language teacher and ten students of a junior high school. The results of this research showed that the teacher interacted with students by 'CROWD' strategy such as 1) recalling prompts, 2) open-ended prompts, 3) Wh-prompts, and 4) distancing prompts. Flander's Interaction Analysis Categories in the CROWD strategy were also identified to see the flow of interaction in the dialogic reading.
\end{abstract}

Keywords: classroom interaction, crowd strategy, dialogic reading, flander's interaction analysis categories 



\section{Introduction}

Classroom is a real social context where its elements (students and teacher) engage in similarly real social relationships (Thomas, 1996). Since a classroom represents a real social context, the interaction between students and teachers in the classroom is an important part of language learning.

Classroom interaction has been regarded as an important factor in gaining real-world communication experience. Interaction in the classroom is a kind of interaction that takes place between the teacher and the students and also among the students in the classroom. A successful teaching and learning process needs interaction with all of the classroom's elements such as students and teacher (Nunan \& Bailey, 2009). Both the teacher and students should have a willingness to participate in the interaction.

Dialogic reading, a strategy of shared interactive reading, can be appropriate to facilitate EFL students' and teacher's interaction in the classroom. The goal of dialogic reading is for the student to become the storyteller and the teacher is an active listener (Zevenbergen \& Whitehurst, 2003). Dialogic Reading can be an alternative for the teachers to develop language skills of the students. Dialogic reading is an approach to learning to read with the help of teaching materials to develop and improve language skills and basic literacy (Lever \& Sénéchal, M., 2011).

Shanty (2016) confirms that dialogic reading strategy is effective to convey learning social, moral, and emotional. Oktavia \& Syafei (2016) mention that dialogic reading strategy helps students speak in a longer sentence, can use more words in English, improving their vocabulary, and practice their English skill. The dialogic reading emphasizes the interaction between adults and children in this case students and teacher, the teacher used a variety of question techniques such as 'PEER' and 'CROWD' strategy of dialogic reading. Some research studies have indicated positive results when implementing the dialogic reading strategy. Fettig et.al (2016) find out that the dialogic reading strategy can help to develop students' social-emotional skills and build the foundation for success in classroom and life.

Watkins (2018) mentions, that dialogic reading can help the development of skills like vocabulary development, oral language, and comprehension, and narrative skills. Moreover, Made \& Budasi (2019) suggest that teacher's teaching competency improves overtime when they used dialogic reading. They were also more confident and capable of engaging with students when learning, which had a direct impact on students reading ability.

Zevenbergen and Whitehurst (2003) proposed a strategy in dialogic reading called CROWD, described as follows:

1. Completion Prompts: In this strategy the teacher should leave a blank of the texts at the end of sentences, to encourage the students to fill it.

2. Recall Prompts: These prompts contain some questions about what happened in a book or text. These prompts help the students to understand the text. They can be used during reading and at the end of reading activity.

3. Open-Ended Prompts: These prompts give the reader the opportunity to tell what is happening in a picture or a text. This can help the students to formulate their own phrases or sentences about the text.

4. Wh-Prompts: These prompts contain what, why, who, when, where, or how questions.

5. Distancing Prompts: These prompts encourage the students to relate what is happening in the text with their own experiences.

Previous studies clearly show that the dialogic reading used in the interaction 
between the teacher and students can improve student's language and literacy skills effectively for students in the first language and students in the second language. However, there are still very limited research studies to investigate how the interaction between EFL students and teachers happens in the use of dialogic reading. To fill this gap, micro ethnography classroom research design was used in this study to get a clear description of the interaction between the teacher and students in an EFL setting. Therefore, this research aims to explore the students and teacher interaction in the dialogic reading strategy.

\section{Method}

This research aims to investigate the teacher and students' interaction of learning reading using the dialogic reading strategy. Therefore, micro-ethnography classroom research is relevant to be used in this study. Micro-ethnography analyzes how interaction is organized socially and culturally in specific situational settings, such as classrooms, where major events of consequence for people's life may occur in the course of daily routines (King, Lai, \& May, 2017).

The participants of this study were an English language teacher and ten students of a junior high school. The teacher in this school has been implementing the dialogic reading strategy when teaching reading.

A field note was used to observe the students and teacher interaction during the implementation of the dialogic reading strategy. The researcher came to the class and observed the participants. The observation data were analyzed with Zevenbergen and Whitehurst strategy of dialogic reading, CROWD strategy. There are, 1) Completion, 2) Recall, 3) OpenEnded, 4) WH-question, 5) Distancing prompts. Flander's Interaction Analysis Categories (FIAC) were also used to identify what kinds of interaction occurred in the dialogic reading strategy.

\section{Findings and Discussions}

This study aims to explore the interaction between students and teachers in dialogic reading strategy when learning descriptive texts. The data of the study were obtained from classroom observation and open-ended interviews with the participants. One English teacher and ten students were observed doing dialogic reading strategy in one meeting lasting for 20 minutes of observation. In this meeting the students learn the topic about descriptive texts.

The title of the text is "My School", and the text contains 87 words with a picture above the text. There were 11 pictures which is divided into 6 slides. Each picture contains with the sentence of the text describing the picture. The students read the text from the screen projector that the teacher showed. Three students have participated in the interview session. They spent about 10 minutes answering the questions. The results of the observation showed what actually happened in the classroom. It showed how the teacher and the students interact with each other. The findings and discussion were explained as follows:

\section{Completion Prompts}

Completion prompts mean that the students should complete the sentences that the teacher gives some gaps in the texts. In this meeting, completion prompts were found with two utterances. The following picture 1 , lists some activities taken from the observation representing completion prompts. 
Picture 1 Completion Prompts

\begin{tabular}{|c|c|c|c|}
\hline Teacher activity & $\begin{array}{c}\text { Students' } \\
\text { activity }\end{array}$ & $\begin{array}{c}\text { CROWD } \\
\text { Categories }\end{array}$ & $\begin{array}{c}\text { Kind of } \\
\text { Interactions } \\
\text { (FIAC) }\end{array}$ \\
\hline $\begin{array}{l}\text { The teacher said, "Yes } \\
\text { that's right. Then please } \\
\text { read this sentence, (It is } \\
\text {... school)" showing the } \\
\text { sentence. }\end{array}$ & $\begin{array}{l}\text { "It is a good } \\
\text { school" }\end{array}$ & $\begin{array}{l}\text { Completion- } \\
\text { prompts }\end{array}$ & $\begin{array}{l}\text { TA: give } \\
\text { direction } \\
\text { SA: students } \\
\text { talk- } \\
\text { responses }\end{array}$ \\
\hline $\begin{array}{l}\text { Next to the last slides of } \\
\text { the text, the teacher read } \\
\text { "(I love my school) } \\
\text { please say it together! I } \\
\text {... my school" }\end{array}$ & $\begin{array}{l}\text { "I love my } \\
\text { school." }\end{array}$ & $\begin{array}{l}\text { completion- } \\
\text { prompts }\end{array}$ & $\begin{array}{l}\text { TA: lectures } \\
\text { SA: students } \\
\text { talk- } \\
\text { responses }\end{array}$ \\
\hline
\end{tabular}

The findings clearly show the teacher gives a blank word of the sentence, so the students can be finish it. For example,

T: "I love my school." repeating said "I .... my school."

S: "I love my school" while reading the texts on the screen.

In addition, there are also interactions in which the teacher giving direction and lecturing, such as,

$\mathrm{T}$ : "please read this sentence, it is .... school" while displaying the sentence on the screen.

S: "It is a good school". (The students repeat the sentence on the screen).

\section{Recall Prompts}

Recall prompts mean that the teacher asked a question about the topic that the students learn. In this meeting, there is only one utterance found as displayed in the following picture 2:

Picture 2 Recall Prompts

\begin{tabular}{|l|l|l|l|}
\hline \multicolumn{1}{|c|}{ Teacher activity } & \multicolumn{1}{|c|}{ Students' activity } & $\begin{array}{l}\text { CROWD } \\
\text { Categories }\end{array}$ & $\begin{array}{l}\text { Kind of } \\
\text { Interactions } \\
\text { (FIAC) }\end{array}$ \\
\hline $\begin{array}{l}\text { "One last question. } \\
\text { Mention, sebutkan } \\
\text { ya fasilitas yang ada } \\
\text { di sekolah apa saja } \\
\text { sesuai dengan } \\
\text { gambar deskripsi } \\
\text { yang tadi } \\
\text { diperlihatkan } \\
\text { coba?" }\end{array}$ & $\begin{array}{l}\text { All the students' } \\
\text { has many facilities, } \\
\text { there are classroom } \\
\text { fifteen", } \\
\text { "laboratorium and } \\
\text { library", } \\
\text { "mosque, sir", } \\
\text { "toilet sir", } \\
\text { "sport field sir, buat } \\
\text { plahraga" }\end{array}$ & $\begin{array}{l}\text { TA: give } \\
\text { direction } \\
\text { SA: students } \\
\text { talk- } \\
\text { responses }\end{array}$ \\
$\begin{array}{l}\text { (“...please mention } \\
\text { the facilities in the } \\
\text { school, according to } \\
\text { the picture that was } \\
\text { showed") }\end{array}$ & & \\
\hline
\end{tabular}

These prompts are used at the end of the learning to allow the students obtain their learning literacy and cognitive processes. It encourages the students to interact with the teacher and react to the teacher's questions. For example, if the teacher asks about the facilities in the school that they have learned, then all of the students tried to respond one by one, such as,

$\mathrm{S}$ : "it has many facilites, there are classroom fifteen", "laboratorium and library", "mosque, sir", "toilet, sir", "sports field, sir for physical exercise".

Furthermore, there are some types of interaction that take place during the teacher and learning process. The teacher's role is giving direction and the student's activity is giving talk responses. For instance, T: "Please mention the facilities in the school! According to the pictures and the texts that were showing."

While showing the pictures on the screen, the students respond by mentioning facilities in the school. That is to reaffirm that the teacher's explanation is quite understandable by the students.

\section{Open-ended Prompts}

Open-ended prompts also occur in this study. There are only two utterances occured in this meeting categorized as open-ended prompts, as displayed in the following Picture 3:

Picture 3 Open-ended Prompts

\begin{tabular}{|l|l|l|l|}
\hline Teacher activity & \multicolumn{1}{|c|}{$\begin{array}{c}\text { Students' } \\
\text { activity }\end{array}$} & $\begin{array}{l}\text { CROWD } \\
\text { Categories }\end{array}$ & $\begin{array}{c}\text { Kind of } \\
\text { interactions } \\
\text { (FIAC) }\end{array}$ \\
\hline $\begin{array}{l}\text { "Okay, we hope she's } \\
\text { getting better soon." }\end{array}$ & "at school" & $\begin{array}{l}\text { Open- } \\
\text { ended } \\
\text { prompts } \\
\text { The teacher is showing } \\
\text { picture as an } \\
\text { apperception for learning } \\
\text { descriptive texts. "see the } \\
\text { picture carefully, do you } \\
\text { know where is it?" }\end{array}$ & $\begin{array}{l}\text { TA: asks } \\
\text { question } \\
\text { SA: students } \\
\text { talk-responses }\end{array}$ \\
\hline $\begin{array}{l}\text { To the next slides, the } \\
\text { teacher asked "So, where } \\
\text { is the place based on the } \\
\text { picture descriptions } \\
\text { showed?" }\end{array}$ & $\begin{array}{l}\text { Raising hand } \\
\text { "parkiran sir", } \\
\text { sekolah sir" }\end{array}$ & $\begin{array}{l}\text { Open } \\
\text { ended- } \\
\text { prompts }\end{array}$ & $\begin{array}{l}\text { TA: asks } \\
\text { question } \\
\text { SA: students } \\
\text { talk-responses }\end{array}$ \\
\hline $\begin{array}{l}\text { ("parking } \\
\text { area, sir", in } \\
\text { front of the } \\
\text { school sir") }\end{array}$ & & \\
\hline
\end{tabular}


The use of open-ended questions by the teacher invites the students to tell or respond to what is happening in the texts. The open-ended font is designed to assist students in forming their own words or phrases in response to the text. For example,

$\mathrm{T}$ : "see the picture carefully, do you know where is it?"

S: "at school."

Students know the answer because they see the picture on the screen displayed by the teacher.

The other method of contact used by the teacher is asking questions, and the students' activity is talking in response to the teacher's questions. It can be seen in the following activity, $\mathrm{T}$ : "where is the place based on this picture description showed?"

S: "parking area, sir," and "in front of the school, sir."

What the students see in the pictures is a wide area in front of the school that is generally utilized for parking, so they can answer the question.

\section{Wh-Prompts}

These prompts contained what, why, who, when, where, or how questions. There are six utterances of wh-prompts by the teacher. This type is the most common type of CROWD that occurred in this meeting. The examples of wh-prompts are as follows:

Picture 4 Wh-prompts

\begin{tabular}{|c|c|c|c|}
\hline Teacher activity & $\begin{array}{c}\text { Students' } \\
\text { activity }\end{array}$ & $\begin{array}{l}\text { CROWD } \\
\text { Categories }\end{array}$ & $\begin{array}{c}\text { Kind of } \\
\text { interaction } \\
\text { (FIAC) }\end{array}$ \\
\hline $\begin{array}{l}\text { Provide a picture display } \\
\text { on the projector screen } \\
\text { "please see the picture } \\
\text { carefully. This is about } \\
\text { bangunan yang ada } \\
\text { dikelas. And who knows } \\
\text { what is it?" } \\
\text { "“... This is about the } \\
\text { things that were in the } \\
\text { classroom. ...") }\end{array}$ & $\begin{array}{l}\text { Raise the hand } \\
\text { "it is room } \\
\text { sir" }\end{array}$ & $\begin{array}{l}\text { Wh- } \\
\text { prompts }\end{array}$ & $\begin{array}{l}\text { TA: giving } \\
\text { direction and } \\
\text { asking question } \\
\text { SA: students } \\
\text { talk-responses }\end{array}$ \\
\hline $\begin{array}{l}\text { Wh-prompts "floor? } \\
\text { What is the meaning of } \\
\text { floor in Indonesia?" }\end{array}$ & $\begin{array}{l}\text { Answered } \\
\text { "lantai pak" } \\
\text { ("floor sir") }\end{array}$ & $\begin{array}{l}\text { Wh- } \\
\text { prompts }\end{array}$ & $\begin{array}{l}\text { TA: asks } \\
\text { question } \\
\text { SA: students } \\
\text { talk-responses }\end{array}$ \\
\hline $\begin{array}{l}\text { The teacher starts } \\
\text { reading the text } \\
\text { "MMy School name is } \\
\text { SMP Negeri } 3 \\
\text { Babakancikao. It is at } \\
\text { Gandasari Village, } \\
\text { Cigelam, Purvakarta. It } \\
\text { is a good school.) So, } \\
\text { where is the school } \\
\text { address?" }\end{array}$ & $\begin{array}{l}\text { Raising hand } \\
\text { "at kampung } \\
\text { gandasari, sir" } \\
\text { "at Gandasari } \\
\text { village, sir" }\end{array}$ & $\begin{array}{l}\text { Wh- } \\
\text { prompts }\end{array}$ & $\begin{array}{l}\text { TA: lectures } \\
\text { SA: students } \\
\text { initiation }\end{array}$ \\
\hline $\begin{array}{l}\text { Give an appreciation to } \\
\text { students "Yes good. } \\
\text { Let's to the next pictures. } \\
\text { (it has many facilities.) } \\
\text { how many facilities of } \\
\text { the school based on this } \\
\text { picture?" }\end{array}$ & $\begin{array}{l}\text { The students } \\
\text { start counting } \\
\text { the building in } \\
\text { the picture, } \\
\text { "six, sir." }\end{array}$ & $\begin{array}{l}\text { Wh- } \\
\text { prompts }\end{array}$ & $\begin{array}{l}\text { TA: asks } \\
\text { question } \\
\text { SA: students- } \\
\text { initiation }\end{array}$ \\
\hline
\end{tabular}

\begin{tabular}{|l|l|l|l|}
\hline $\begin{array}{l}\text { To the next slides, the } \\
\text { teacher read "(There is a } \\
\text { beautiful garden, in the } \\
\text { besides of the school.) } \\
\text { okay, I will ask a } \\
\text { question. What is a good } \\
\text { place besides school?" }\end{array}$ & $\begin{array}{l}\text { "mmm, itu } \\
\text { taman ya sir" } \\
\text { ("that is } \\
\text { garden sir") }\end{array}$ & $\begin{array}{l}\text { Wh- } \\
\text { question } \\
\text { prompts }\end{array}$ & $\begin{array}{l}\text { TA: asks } \\
\text { question } \\
\text { SA: students } \\
\text { talk-responses }\end{array}$ \\
\hline $\begin{array}{l}\text { The teacher asked, "what } \\
\text { is the meaning I love my } \\
\text { school in Indonesian?" }\end{array}$ & $\begin{array}{l}\text { "Aku cinta } \\
\text { sekolahku" }\end{array}$ & $\begin{array}{l}\text { Wh- } \\
\text { prompts }\end{array}$ & $\begin{array}{l}\text { TA: asks } \\
\text { question } \\
\text { SA: students } \\
\text { talk-responses }\end{array}$ \\
\hline
\end{tabular}

This type is the most common type of CROWD that occurred in this meeting. Wh- is all about questions containing $5 \mathrm{~W}+1 \mathrm{H}$. For example,

$\mathrm{T}$ : "who knows what is it?"

$\mathrm{S}$ : "it is room sir".

Another example, after reading the next few phrases,

T: "what is a good place besides the school?"

S: "that is garden, sir"

The students can answer the question because they see the picture as an area with a lot of plants.

In Flanders' Interaction Analysis Category, wh-prompts are characterized as teacher's talk of asking questions, giving direction, and lecturing to the type of interaction in these prompts. Therefore, the teacher frequently asks questions related to the material being studied during the session to improve students' comprehension and confidence in answering the questions.

\section{Distancing Prompts}

The aim of distancing prompts is to help the students relate between the texts and the student's daily life. It can help verbal fluency, conversation, and narrative skills. During the meeting, there was only one utterance of distancing prompts. The following Picture 5, represents distancing

\begin{tabular}{|c|c|c|c|}
\hline Teacher activity & $\begin{array}{c}\text { Students' } \\
\text { activity }\end{array}$ & $\begin{array}{l}\text { CROWD } \\
\text { Categories }\end{array}$ & $\begin{array}{l}\text { Kind oo } \\
\text { interaction } \\
\text { (FIAC) }\end{array}$ \\
\hline $\begin{array}{l}\text { "Good job rio. Thank } \\
\text { you. Jadi, biasanya } \\
\text { kalian belajar }\end{array}$ & "dilapangan", & $\begin{array}{l}\text { Distancing- } \\
\text { prompts }\end{array}$ & $\begin{array}{l}\text { TA: praises } \\
\text { or } \\
\text { encourages }\end{array}$ \\
\hline $\begin{array}{l} \\
\text { (“... So where are you } \\
\text { usually doing a } \\
\text { physical exercise } \\
\text { lesson?”) }\end{array}$ & ("at sports field") & & $\begin{array}{l}\text { SA: } \\
\text { students } \\
\text { talk- } \\
\text { responses }\end{array}$ \\
\hline
\end{tabular}




\section{Picture 5 Distancing Prompts}

Distancing prompts occurred in this meeting. The teacher relates the pictures in the text to the students' interpretations of what they see and know, linking to their own experiences. When the teacher gives praises, the teacher also asks about relates to the texts on the screen

T: "So, where are you usually doing a physical exercise?"

S: "at the sports field, sir".

The teacher's lecturing, praising, or encouraging were examples of interactions that occurred in this situation. When one of the students is requested to read a sentence in front of the class during class interaction, the teacher gives praise. Several forms of student talk-responses are based on what the students see or understanding.

\section{Conclusion}

The use of dialogic reading strategy on student-teacher interaction has been explored in this research. The teacher employs many interactive activities in the classroom. It can be seen from FIAC analysis described previously in the findings. In the dialogic reading activities, the teacher uses CROWD strategy including completion prompts, recall prompts, openended prompts, Wh-prompts, and distancing prompts.

Furthermore, the use of dialogic reading strategy requires planning of using various and interesting media for the students. Using a textbook or pictured text displayed on the screen projector may increase the students' motivation to participate in the classroom activity. The media and the dialogic reading activity gave the students opportunity to interact with their teacher. The teacher interact with their students by giving direction, praising or encouraging, asking questions, and lecturing.

\section{References}

Fettig A, S. T. (2016). Storybooks and beyond: teaching problem solving skills in early childhood classrooms. Young Exceptional Children 19, 1831.

Giorgdze, M., \& Dgebuadze. (2017). Interactive Teaching Methods: Challenges and Perspectives. IJAEDU-International E-Journal of Advances in Education 3(9), 544548.

Gold, J. G. (2001). Reading aloud to build comprehension[online]. Available at:

http://www.readingrockets.org/artic le/343.

Irtube, C. Z. (2019, 4 18). World of Better Learning: Pedagogy What is Dialogic Reading? Retrieved 4 14, 2020, from Cambrige University Press:

https://www.cambridge.org/elt/blog/ 2019/04/18/dialogic-reading/

King, A. K., Lai, Y. J., \& May, S. (2017). Research Method in Language and Education. Springer Link, 435-447.

Lever, R. \&., \& Sénéchal, M. (2011). Discussing stories: How a dialogic reading intervention improves kindergarteners' oral narrative construction. Journal of Experimental Child Psychology, 108, 1-24.

Made, R. N., \& Budasi, I. G. (2019). Pemanfaatan Dialogic Reading: Kompetensi Mengajar Guru dan Kompetensi Membaca Siswa. Prosiding SENADIMAS Ke-4. Bali: eproceeding undiksha.

Nasir, C., Yusuf, Y. Q., \& Wardana, A. (2019). A Qualitative Study of Teacher Talk in an EFL Classroom Interaction in Aceh Tengah, 
Jurnal Edumaspul, 5 (2), Year 2021- 366

(Annisa Sita Herdanti, Hilmansyah Saefullah)

Indonesia. Indonesian Journal of Applied Linguistics, 523-535.

Oktavia, \& Syafei, A. R. (2016). USING

DIALOGIC READING

STRATEGY TO TEACH

ENGLISH TO TEACH YOUNG

LEARNERS. Journal of English

Language Teaching, 121-126.

Shanty, L. M. (2016). Preschool children's emotion knowledge: Storybooks as a learning tool (Order No.

10140618). Available from

ProQuest Dissertations \& Theses

Global.

Watkins, P. (2018). Extensive Reading for

Primary in ELT. Part of the

Cambridge Papers in ELT series.

Cambrige University Press.
Zevenbergen, A. A., \& Whitehurst, G.

(2003). Dialogic reading: A shared picture book reading intervention for preschoolers. In I. A. Kleeck, S. S.A, \& B. E.B, On reading books to children: Parents and teachers (pp. 177-200). Mahwah, NJ: Lawrence Erlbaum Associates.

Zevenbergen, A. A., \& Whitehurst, G. J. (2003). Effects of a shared-reading intervention on the inclusion of evaluative devices in narratives of children from low-income families. Journal of Applied Develompmental Psychology, 24, 1-15. 